\title{
Understanding Contributions of the Creative Class to Sustainable Economic Growth in China
}

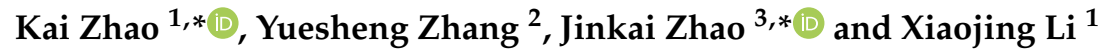 \\ 1 School of Economics and Finance, Xi'an Jiaotong University, Xi'an 710061, China; lixj95@stu.xjtu.edu.cn \\ 2 School of Economics and Management, Tianjin Chengjian University, Tianjin 300384, China; \\ zhangys@tcu.edu.cn \\ 3 College of Economics and Management, Shandong University of Science and Technology, \\ Qingdao 266590, China \\ * Correspondence: kaizhao@mail.xjtu.edu.cn (K.Z.); jinkai_sdust@163.com (J.Z.)
}

Received: 14 January 2020; Accepted: 8 February 2020; Published: 11 February 2020

\begin{abstract}
By investigating the direct effect of the ' $3 T^{\prime}$ 's (the creative class; tolerance; technology) and their interactive effects on GDP per capita, based on the data collected from 279 cities over the period of 2002-2014, the aim of this study is to explore the practical value of the creative class theory to the sustainable economic development in China. Using econometric estimations; the results suggest that agglomeration of the creative class; improving tolerant milieu and increasing technology investment have positive explanatory powers in understanding the disparities in GDP per capita between different cities in China. However, the complementary effects on GDP per capita are only observed between the creative class and technology or technology and tolerance, while there is an interference effect between the creative class and tolerance. These findings suggest that Florida's advocacy for generating creative competitiveness across cities and regions by building up selected amenities may be arguable, but that the creative class is substantially contributing to regional economic growth. However, the creative class may have a unique mix with other innovative elements in different contexts. Therefore, instead of extensively focusing on a 'one-size-fits-all' solution that praises 'cultural consumption', the present study suggests a 'three-phrase theory'; which has quite generic and flexible policy focuses on different development stages.
\end{abstract}

Keywords: the creative class; tolerance; technology; economic growth; Florida

\section{Introduction}

In the context of intensified global competition for innovation, the capacity to mobilize, attract and utilize innovative talent has become an important factor in determining the potential for innovation and sustainable development for a region or country. When formulating innovation-driven development strategies, decision-makers have shown a strong demand for, not only a few selected people with superior talents, but also many other knowledge-based workers during the production process. Therefore, strengthening the 'group effect' and 'growth effect' of innovative talents on socio-economic development and understanding how to enhance their innovation and career vigor has widely attracted the attention of scholars [1].

Under this dominate milieu, the creative class theory, with many attractive claims, such as fully exploring the potential of different occupations (e.g., scientists, university teachers, high-tech technicians, artists, journalists, mangers or other types of knowledge workers) as a joint force of creativity or building-up selected 'cultural' amenities to attract creative workers which in turn acts on the sustainable economic growth of a city or region, has become a focus. Since Richard Florida put forward the theory of the creative class in 2002, numerous studies have explored the relationship 
between improving innovation capacity and socio-economic development from the perspective of 'occupation division' ([2-4], etc.). In recent years, such a concept has increasingly been favored by decision-makers with the proliferation of the concept of creative city and regional innovation system (e.g., [5,6], etc.).

The growing visibility and popularity is accompanied by the intensive criticism regarding many of the policy standpoints held by Florida that cannot be approved in the socio-economic reality [7-12]. For instance, Glaeser [13] claimed that the effect of the creative class on economic growth is empirically similar to that of the traditional human capital measure. Boschma and Fritsch [14] further added that the causal relationship between economic performance and the presence of the creative class cannot be identified by simple statistic models, such as an Ordinary Least Square (OLS) regression. In addition to these technical issues, it seems that some of the basic assumptions of the creative class theory are also not plausible $[15,16]$; the relationship between the spatial distribution of the creative class and the level of tolerance can be bi-directional and may not be verified in the context of non-metropolitan areas. All these evidences imply that the original theoretical framework proposed by Florida needs to be further revised and improved.

Compared to the early debate that intensively focuses on Florida's policy stand points, such as building up a 'tolerant' environment, the notable feature of the present research is that the concept that the creative class has been considered as an important theoretical point of integration, which links different socio-economic development theories together. There are plenty of studies from this perspective, such as Stolarick and Currid-halket [17], who revealed the creative class is more resistant to unemployment, compared to other work groups, and Luger [18] and Trillo [19], who held a positive attitude towards the role of the creative class in the optimization process of the economic network. The latest research is Zhao et al. [20], who found that there is a complementary relationship between the regional density of the creative class and the use of ICT in Europe. In this sense, the on-going and intensive debates regarding regional development have not avoided the concept of the creative class. Rather, we have to envisage that the creative class thesis has had a profound influence on the empirical and theoretical development of regional studies, only opening up new lines of discussion regarding how the concept of creativity can be applied in a broader context of socio-economic development.

Along this line of thought, the purpose of this paper is to embed the idea of the creative class in a more standard economic growth framework and to verify the practicability of the creative class theory based on the reality of China's economic development. Therefore, we seek appropriate answers to the following research questions: (1) How does the creative class impact on regional economic growth in China? (2) are there links between the use of creative inputs and other economic determinants that Florida advocated, such as technology and cultural environment? It is important to state at the outset that our analysis does not focus on validating the theoretical framework of the creative class thesis in a non-western context. Instead, based on the context of China, we expect to bring more insights about how a particular talent group plays decisive roles at different stages in converting a new idea or creativity into a successful innovation and concrete economic outcome; in which aspects of the development of the innovative talent group are currently restricted by immature urban construction, networking mode and innovation incentive system; and finally how policy makers can solve these issues.

Compared to existing research, this study provides four main contributions to the current literature. First, China is used as the prime example, as it is now experiencing dramatic socio-economic changes that appear to be deeper and more significant compared to developed countries over the last 2-3 decades, but few studies have explored the possible effect of talent group on its economic development [21]. Given the significant cultural and institutional differences, the findings mainly based on the northern America or Europe may be not generalizable to China. Second, a macro-model that integrates the creative class with other dimensions of the knowledge economy incorporating the idea of factor complementarity is adopted. We highlight the reconstruction of the original creative class theory, and that the values of the creative class depend on its level of contact with other factors 
within the eco-social system. In other words, creativity on its own is not sufficient for growth and social change, but needs to be seen in light of the use of other factor inputs, production processes and technological progress. To the best of the authors' knowledge, this is one of the few studies that discuss the collaborative mechanism and optimization path of the newly emerged innovative group from the perspective of sustainable growth. Third, although some Chinese studies have investigated the role of the creative class at the provincial level or based on a selected group of cities (e.g., [22,23]), issues, such as different statistical range and missing data have impeded the interpretation of the findings. In comparison, this study constructs a novel measure to elucidate the differences between the creative class and non-creative workers based on the available data in China, providing viable directions for future research. Finally, this study provides meaningful references for policy makers either, in China or worldwide for guiding and inspiring local occupational groups to form 'innovation communities', which can further integrate and improve innovation networking and allocation of resources in various contexts, such as building up smart cities and open innovation systems or developing creative industries.

The remainder of this paper is organized as follows. The next section provides a literature review on the creative class. Section 3 introduces the methodological approach employed in the paper and describes the data. Section 4 demonstrates the main results from various perspectives and Section 5 concludes the paper.

\section{Literature Review and Hypothesis Development}

\subsection{Historical and Theoretical Background}

Human capital is defined as the ability attached to the workforce, which can further generate economic value and increase productivity. However, 'ability' as an abstract concept is difficult to quantify concretely, so the measurement of human capital has evolved into various forms in both theoretical and empirical studies, such as the degree of education [24], entrepreneurship [25], individual and collective human capital [26]. Apart from these studies, there is another strand of literature that focuses on the role of occupational groups in economic development (e.g., [2,25,27-29]), exploring a 'joint force' of innovative ability of different occupations to regional and urban development. For instance, creativity is described by Florida [2] as creativeness, and he believes that only with the division of labour can people unite firmly to form a 'community', and perform the function of social resource integration, so that occupational groups can interact frequently in production and life, produce cooperative and shared values, and ultimately promote social and economic development. With this in mind, the creative class thesis may be similar to the traditional human capital theory to some extent, but its elaboration on the innovation ability based on the diversity and complexity of the social structure is rather novel. The creative class is not a simple division of occupational groups, but a consistent and concentrated expression of self-cognition and values in the new economic status.

Florida divides the overall workforce into the agricultural class, the service class, the manufacturing class and the creative class, and the creative class is further divided into the super creative core, the creative professionals and the bohemian people according to the level and feature of creativity (See Appendix A). The creative class yearns for multiple experiences, advocates a multidimensional lifestyle, and is able to work in a constantly changing and innovative environment with ease, which will eventually produce great innovative economic value [30]. If the creative class is attracted by the high-quality soft and hard environment and gathers together to work and live in a region, then innovation-driven resources, such as high-tech industry and other types of human capital will also interact with the creative class, fully display their own potential, and gradually form an innovative economy system with scale. This system will become a stronger magnet that will attract more people of all kinds to work and live, and eventually create a virtuous cycle of constant innovation and job growth.

To sum up, the core content of the creative class theory can be summarized as follows: (1) At the formation level: The formation of the creative class is significantly different from other social 
groups, that is, the creative class has a more detailed boundary of class behavior, and has formed the corresponding class cognition, economic function and social identity; (2) at the collaboration level: The richness of innovation-driven elements, the density of the creative class and the complementary effects between them are important determinants in the development of urban or regional economy; (3) at the optimization level: What determines the sustainability of economic development is the composition and the quality of the innovation network which intertwines the creative class with other important factors. Although various studies, in the past 15 years, have shown significant differences in terms of research motivation, methodology, modelling or variable definition, the strand of literature can still basically be classified into these three categorizes.

\subsection{Research on the Formation Mechanism of the Creative Class}

The research on the formation mechanism mainly includes the following two aspects: The first is about exploring the formation process of the creative class, including the historical background, geographical connection, economic development, the necessity and feasibility of the formation, and the like. A large amount of literature shows that, whether in North America, Europe or other parts of the world, due to the development of the creative economy and the urgent desire for an economic transition, the regional density of the creative class has been increasing in the past two decades, and has brought about significant economic and social benefits. For example, during the 11 years from the publication of The Rise of the Creative Class in 2002 to 2013, the number of people employed in manufacturing in the United States fell from 32 million to 26 million, while the number of people employed in the creative class rose by 2.8 million. Even during the economic crisis in 2008, the unemployment rate of the creative class was only half other types of jobs [30], reflecting its strong market survival ability and adaptability [17]. The second is about examining the externality of the agglomeration of the creative class. Florida believes that the formation mechanism of the creative class is fundamentally different from that of traditional human capital, so the expression of economic contribution is also different: Human capital measured by higher education is more suitable for the measurement of income change, while the creative class defined by creativity has more say in the change of productivity [27]. McGranahan and Wojan [31] and Marlets and Van Woerkens [32] also hold a similar view that the formation of the creative class is indeed important in explaining regional economic development from quite a different perspective. However, much literature believes that early research on the formation mechanism of the creative class shows many issues in model specification and indicator selection. The original theoretical model, for example, is difficult to prove the causality Florida claims in the empirical analysis [14], and there exist econometric issues, such as endogeneity or multicollinearity [33]. Therefore, it is not easy to portrait the evolving pattern of the creative class from a spatial-temporal perspective.

\subsection{Research on the Collaborative Mechanism of the Creative Class}

At the same time, many scholars focus on how to collaboratively link the presence of the creative class with other socio-economic factors in the context of urban and regional theories $[7,10,34,35]$. This strand of literature can be generally summarized as follows:

First, the philosophical underpins of the creative class concept are discussed. The definition of the creative class includes both white-collar workers, with higher education and senior technicians who put practical experience and operational skills, which is not significantly different from the traditional definition of the high-skilled group [13,36,37]. However, it has to be admitted that accurately capturing the contribution of creativity is also a challenging task for both academics and policy makers.

Second, the values of the creative class are heterogeneous. There is yet no consistent conclusion about whether the creative class, based on various occupations, shares the same values and preferences. It seems that only people can better understand its value orientation by dividing the creative class into smaller labour units [10,38]. For example, Asheim and Hansen [39] proposed and analyzed the concepts of creative occupation, comprehensive creative occupation and symbolic creative occupation, which were respectively matched with scientific atmosphere, commercial atmosphere and artistic 
atmosphere. Kratke [40] further excluded the employees related to finance and politics, and defined the remaining creative subgroups as scientific and technological creators, occupational creators and artistic creators. Third, we analyzed whether the cultural environment promotes the 'innovation growth' effect of the creative class. Many empirical studies have found the hypothesis that 'highly tolerant society attracts more creative talents' can only be verified when the samples selected are large cities in North America [10,41,42]. Many small and medium-sized cities do not have the basis to develop social diversity and variety, but the innovation economy has also developed rapidly in the past 20 years $[43,44]$.

There are many similar studies (e.g., [45]). However, even though these studies show the preliminary idea of constructing the collaborative development mechanism with the creative class, due to data or model constraints at that time, the specific investigation has not been completed. Also, some studies pay too much attention to the relationship between building up a cultural environment and economic innovation, thus to a certain degree, neglecting the mediating effects of other important socio-economic drivers, such as institution or technological progress on the creative class.

\subsection{Research on the Optimization Mechanism of the Creative Class}

Compared with the research on formation mechanisms and collaborative mechanisms, the research on the optimization mechanism of the creative class was formed relatively late, which is more likely to be a summary of the issues reflected in previous literature, and aims to further expand the application dimension of the creative class theory from the perspective of interactive and optimizing effect of the creative class on innovation networking. It is not surprising to see that research regarding the creative class theory evolves in this way, as many studies have provided solid evidence that the growth momentum does not derive from the simplistic accumulation of production factors, but from well-organized and coordinated innovative activities [46]. For instance, Yun and Lee [47] proposed a 'city $\times$ connectivity $\times$ entrepreneurship' model for developing Smart 4.0 city, and entrepreneurship, as a particular type of creativity embedded to creative occupations such as creative professionals, is essential in connecting different innovative factors together. Krishna [48] suggested that creative education, as an important part of national innovation system, can produce knowledge workers with creative skills, thus should be clearly supported by innovation and science policies. Kodama [49] claimed that the creation of new business model accelerates the industrial transformation of automobiles, but again, the dramatic technological change is supported by experienced workers and managers. Even though these studies have different perspectives, such as increasing productivity or building an innovation system, they converge where there is an urgent need to have an appropriate institutional setting. In this sense, openness or inclusion, is not only a fundamental condition to attract all socio-economic agents, but more importantly, to create an innovation system with less clear borders that individuals, firms and industries can share and coordinate resources to realize innovation and associated outcomes [50].

With this in mind, the recent creative class literature starts to only take some of the concepts as theoretical 'puzzles', which are combined with other economic and innovation theories, to explore the 'usefulness' of the creative class theory on the optimization of innovation structure and the realization of sustainable development. For example, $\mathrm{Wu}$ [51] argued that integrating the creative class theory with the creative industry theory and the theory of global production networks is an effective approach to better understand the high-quality regional economic development, as the creative class owns creativity based on the nature of work and task, which is able to increase the 'thickness' of production organization's structure(i.e., knowledge is open to flow), and help to accelerate the interactive process regarding learning, innovation and economic and social value transformation. Mellander et al. [52] found that, compared with non-creative labour groups, the creative class, with characteristics of openness and tolerance, is able to improve work efficiency and obtain higher salaries in a social networks, using creative and communication skills. Based on the definition of the creative class occupation, Batabyal and Yoo [53] built a smart city innovation ecosystem, incorporating factors, such as creative occupations, competitive market, government's innovation policy and R\&D 
investment. One of the conditions to achieving a balanced growth path (BGP) was found to be R\&D investment in different innovative occupations, otherwise growth is not balanced. Trillo [19] also holds a positive attitude towards creative class features in the optimization process of knowledge 'network'. In summary, the present creative class theory has expanded its research frontier to the context of innovation synergies, also to a certain extent, enlightens the present research domain of open innovation with an empirical and theoretical possibility that could detail the powers of alternative innovative factors, such as tolerance, in addition to the focus on human's creativity.

\subsection{Research Hypothesis Development}

Overall, the evolving trajectory of the creative class theory can be generally divided into three stages, since its initialization in 2002: At the first stage, early research started with verification of the original framework of the creative class theory, and emphasized the study of its formation mechanism; at the second stage, the focus on the collaborative mechanism was no later than the research on the formation mechanism. However, as long as the concept of quality development and collaborative development is becoming increasingly popular, the amount of related research significantly increases. Finally, the interdisciplinary study of optimization mechanism, points out a new direction for the development of the creative class theory.

By contrast, the creative class research in China is at a primary stage and characterised by:

First, due to historical reasons, scholars tend to claim 'creative talents' and 'creative industries' instead of 'creative class', where there was no clear distinction between these concepts despite the early literature more or less mentioned the principle of the creative class, which has led to a lack of understanding about the formation mechanism of the 'specified' creative class. Although, these studies simultaneously involved the concept of creative talents, industries or talent group, the creative class theory was not directly used to clarify the logic of how the presence of creative talents could bring about their economic effects. Hence, we propose Hypotheses 1 as below:

Hypotheses 1 (H1). A higher level of the regional density of the creative class, in association with other socio-economic factors that Florida advocates, is positively related to the economic growth in China.

This is a first step in extending the previous studies to qualify the magnitude of the creative input and explore whether the agglomeration of the creative class do exist and that it has a significant and direct effect on regional growth in China.

Second, since 2006 the research in the true sense on the creative class theory and its practice began to appear in China (e.g., [21], etc.). However, due to a lack of a deep understanding of the connotation of the creative class theory, most studies did not make a dialectical analysis of the original theoretical framework, ignored the discussion on the formation mechanism and jumped directly to the level of collaborative mechanism. For example, Hong et al. [22] analyzed the preferences of the creative class. Based on the research on the panel data of 30 provinces in China from 2003 to 2007, cultural opportunities, higher education and high-tech indicator were considered as the determinants of the location of the creative class. Wang et al. [23] made an empirical analysis of the creative class, knowledge externality and urban innovation in 21 large cities in China. The findings revealed that the rise of the creative class can bring new social wealth, and can serve as an important force affecting the innovative growth of urban economy. However, there are still various issues, such as vague analytical method or scattered focus and the existing literature has not yet involved optimization mechanism research, thus it lacks recognition with regards to allocating innovation resources by the creative class, and then building an efficient adaptation mechanism for talent groups. This study thereby hypothesizes the following:

Hypotheses 2 (H2). The effect of the creative class on economic growth is likely to be strengthened through technological progress and building up a 'tolerant' milieu. 
In this second step complementarity between the presence of the creative class and the development level of technology or tolerance is investigated. We use Florida's '3T' (talents, technology and tolerance) concept, but with a quite different perspective and econometric framework, to evaluate the interactive effects between these factors. This approach tests both how the concept of the creative class can be situated in China's reality and how the quality of innovation system can be improved through the cooperation of innovative factors. We expect to bring more insights on how the concept of the creative class can be revised and further integrated with other theoretical domains, thus enriching the literature on factor complementarity and optimization in regional economic development.

\section{Research Specification}

\subsection{Theoretical Framework and Model Specification}

Following Widen et al. [54], the present study constructs the analytical model based on the theory of urban innovation system. It assumes that urban innovation system needs not only the creative inputs, but also specified combinations of actors. As Figure 1 shows, the model considers the regional economic development can be achieved through four mechanisms: (1) The emergence of talent groups, such as the creative class; (2) spatial and institutional environment, such as reputation, historical background, the level of technological development, social provision and tolerant milieu; (3) networks, namely the complementary relationship between talent groups and institutional variables; (4) external factors, such as market opportunities and policy interventions. Therefore, we explicitly construct the basic model that can effectively reflect the features of an urban innovation system mentioned above as:

$$
\begin{aligned}
\text { GDP per capita }_{i, t} & =\alpha_{i}+\beta_{1} \text { The creative class }_{i, t}+\beta_{2} \text { Tolerance }_{i, t} \\
& +\beta_{3} \text { Technology }_{i, t}+\beta_{4} \text { Interative terms }_{i, t}+\beta_{5} \text { Universities }_{i, t} \\
& +\beta_{6} \text { Theaters }_{i, t}+\beta_{7} \text { Green land }_{i, t}+\beta_{8} \text { Wage }_{i, t} \\
& + \text { Year dummies }+ \text { City dummies }+\epsilon_{i, t}
\end{aligned}
$$

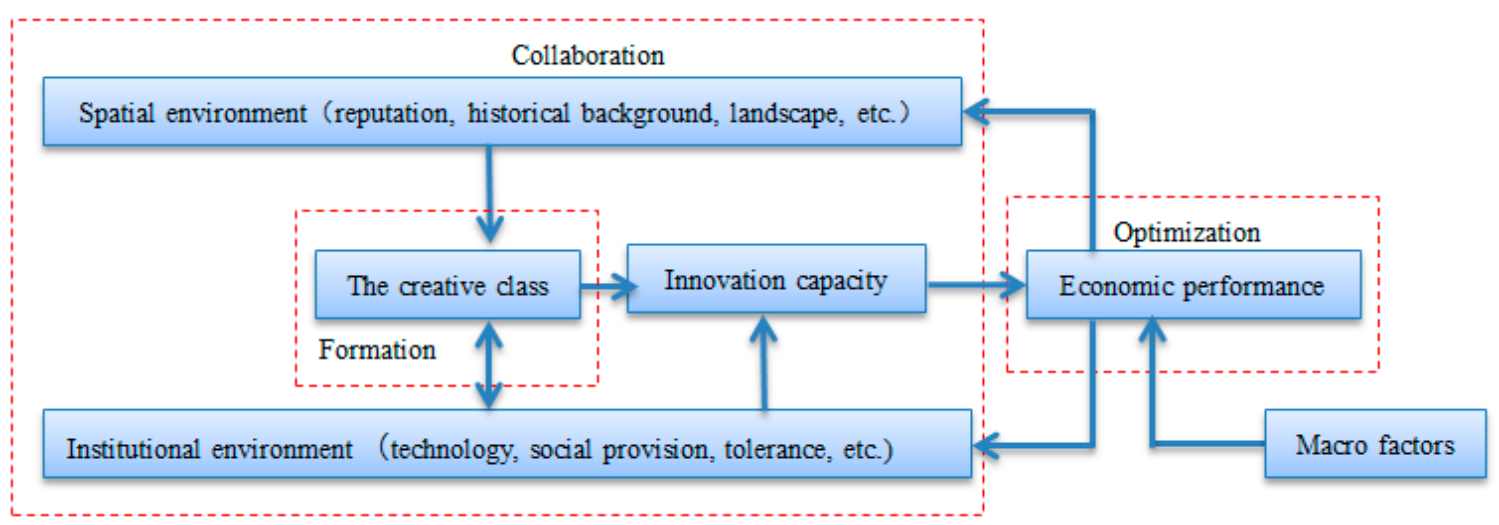

Figure 1. Theoretical framework.

Equation (1) shows that GDP per capita, namely the economic performance, is expressed as the function of institutional actors including density of the creative class, the level of tolerance, the level of technological progress, the number of universities per 10,000 population, the number of theaters per 10,000 population, the square hectare of green land per 10,000 population and macro factors represented by average wage for city $i$ at time $t$, and with a further inclusion of year dummies and city dummies. Year dummies were used for controlling common time trend effects. Cites dummies were added to control the heterogeneous individual effects among different administrative cities. Theoretically, spatial environment related factors, such as historical background shall be also incorporated in the model, but they are difficult to access at the city level and the fixed effects model (i.e., with city dummies) was 
expected to eliminate the potential endogeneity caused by these unobservable time-invariant factors in the error terms.

Concerning the role of networking within a regional innovation system, the interactive terms between technology and the creative class, technology and tolerance, and the creative class and tolerance were further included in the model, respectively, for the purpose of examining the interactive effects between these factors on the growth of GDP per capita. The addition of interaction variables dramatically changed the interpretation of all of the coefficients. The total effect of a variable depended, not only on its own coefficient, but also on the coefficient of the interactive term and the values of its interacted variable.

Regional analysis always involves many econometric issues, particularly for a longitudinal dataset. Therefore, dynamic GMM model, which is commonly used in regional studies, is employed in order to efficiently tackle endogeneity, heterogeneity and simultaneity. The typical fixed effects model may suffer from the problem of model misspecification, thus the basic model can be further extended to an autoregressive panel model such that:

$$
\begin{aligned}
& \text { GDPpercapita }_{i, t} \\
& =\alpha \text { GDPpercapita }_{i, t-1} \\
& +\beta_{1} \text { Thecreativeclass }_{i, t}+\beta_{2} \text { Thecreativeclass }_{i, t}-1+\beta_{3} \text { Tolerance }_{i, t}+\beta_{4} \text { Tolerance }_{i, t}-1 \\
& +\beta_{5} \text { Technology }_{i, t}+\beta_{6} \text { Technology }_{i, t}-1+\beta_{7} \text { Interactiveterms }_{i, t}+\beta_{8} \text { Interactiveterms }_{i, t}-1 \\
& +\beta_{9} \text { University }_{i, t}+\beta_{10} \text { University }_{\mathrm{I}, \mathrm{t}-1}+\beta_{11} \text { Theater }_{\mathrm{I}, \mathrm{t}}+\beta_{12} \text { Theater }_{\mathrm{I}, \mathrm{t}-1} \\
& +\beta_{13} \text { Greenland }_{\mathrm{I}, \mathrm{t}}+\beta_{14} \text { Greenland }_{\mathrm{i}, \mathrm{t}-1}+\beta_{15} \text { Wage }_{\mathrm{i}, \mathrm{t}}+\beta_{16} \text { Wage }_{\mathrm{i}, \mathrm{t}-1}+\text { Yeardummies } \\
& +\mu_{\mathrm{i}, \mathrm{t}}
\end{aligned}
$$

where the dependent and independent variables in Equation (1) are no longer only determined by their current levels, but are also pre-determined by the levels in the past.

\subsection{Data}

Unlike previous research, this study is unique in employing a comprehensive approach to a better extension of depth and breadth of dataset, which in turn, facilities the in-depth econometric analyses mentioned above. The dataset used in this study when generating variables at the city level came from the China City Statistical Yearbook and contains a large sample based on 279 cities over the period of 2002-2014. However, only the data of urban districts was included, due to the reclassification of spatial units over the time period. Given the inconsistency in the occupation classification standard between the United States and China, the creative class defined in the Statistical Yearbook could not completely match Florida's construction. Although survey-based datasets, such as The Labor Force Survey in China and China Health and Retirement Longitudinal Study, have provided a similar category of creative occupations, the samples were limited to the city level. In other words, to our best knowledge there are no existing estimates of creative occupations at the regional level which could enable calculation of talent index in China.

The regional density of the creative class: the variable of 'Persons Employed in Various Units by Sector' was used to calculate a proxy measure. As the data description shown in Appendix A, this measure included most of the creative workers, such as scientists, higher education teachers, artists, employees in social services and finance sectors, without significantly overlapping with non-creative occupations. However, it is worth mentioning that a few creative occupations defined by ISCO (International Standard Classification of Occupations) may be not included. For instance, chief executive officer (ISCO-88 code: 121) may exist in different sectors, whereas senior government officer (112) and social work associate professionals (346) belong to the sector of social service, but most employees within this category are not creative workers. 
GDP per capita: the deflated value of GDP per capita was based on the year of 1990 and log-transformed. It is defined in a usual way as the natural logarithm of the total GDP divided by the total population for city i at time $t$.

Tolerance: the debate regarding how to accurately define the level of tolerance has arrived at mixed conclusions. Florida et al. [55] used the ratio of gays and lesbians to the total population as an indicator. In addition, this factor was also measured by the locational quotient of 'bohemians' (e.g., [56]) or the ratio of foreign born workforce [34] in the European context. In an initial analysis on the creative class in China, Florida et al. [55] replaced the index of gay and lesbian population with a ratio of non-household population over total population, but this indicator is difficult to collect at the city level. Hence, following Lorenzen and Anderson's approach [57], the tolerance at the city level in China was measured in this paper according to the locational quotient of employees engaged in cultural, education, broadcasting and movie sectors.

Technology: the development level of technology is commonly measured by the ratio of output of high-tech industries to the total output [27] or patents number per 1000 population [14]. Given that data for constructing these indicators is unobtainable at the city level in China, the present study adopted the ratio of technology expenditure to total financial expenditure of local government as a proxy. This could be deemed realistic in China's context, as the support from local government and research institutions, rather than the contribution of enterprises and individuals, is the vital factor in determining the local technological improvement.

Cultural opportunity and social provision: The significance of these indexes was to account for the effects of the social welfare system and other factors that Florida advocated in determining the creative 'milieu'. It is assumed that a city with more green space, universities, theaters and education institutions provide local residents with better working and living environment. The number of universities, square meters of green space and the number of theaters for city $i$ at time $t$ are measured in the unit of per 10,000 population

Macroeconomic condition: In addition, we include a variable of average wage to account for macroeconomic shocks for different cities. A higher level of average wage implies a more stable economic situation, in general, with an improvement in employment and enterprise benefit, which in turn, acts on the economic performance of a city or region. Due to data constraints, it is difficult to incorporate other commonly used indicators.

\section{Econometric Results}

\subsection{Statistic Summary and Correlation Test}

Table 1 presented a statistical summary of the variables included in the regressions. The logarithmic value of GDP per capita varied from 9.19 to 4.56 with the standard deviation being 0.70 . Some of the independent variables exhibited even greater variation. For example, the value of technology index varied between 9.93 and 0.010 and the value of tolerance between 7.81 and 0.017 . On average, creative workers only accounted for 3.9 percent of all workers, with a large standard deviation. Hence, as described below, analytical models were adopted from different perspectives to obtain robust results. The correlation test (Table 2) suggested that most of the variables were positively correlated to GDP per capita, reaching the level of significance $(p<0.01)$. The small size of coefficients implied that the model employed in this study was unless likely to encounter multicollinearity issues. The only exception, however, was the coefficient of the creative class ratio and the location of bohemians. The reason might be that, as Florida argued, workers following artistic occupations were the bohemians who favored local amenities. Hence, they indicated a region's capacity to attract other creative workers.

\subsection{Descriptive Analysis}

The main goal of this section is to assess the spatial distribution of the main variables, namely the density of the creative class, the level of technological development and the level of tolerance 
at the city level in China. The overall level of these variables was outlined before considering their variation over time so as to provide useful information. Figures $2-4$, respectively, show the locational quotients of the average ratios of the creative class, bohemians and technological investments over the period of 2002-2014. Figure 2 demonstrates that first-tier cities and provincial capitals employ far more creative workers in eastern and southern regions. A similar pattern could be captured in a few capital cities in western regions, such as Urumchi, Yinchuan and Lanzhou. In particular, the density of the creative class was much higher in first-tier cities, including Beijing, Shanghai, Guangzhou or Shenzhen than that in other regions. Next, the quality of regional milieus was considered, as shown in Figure 3. The findings revealed that the distribution of bohemians was, to some extent, similar to the distribution of the creative class. It is not surprising to see that eastern and southern regions also had significantly higher proportions of the bohemian population. However, among other regions, only a few could be identified as being rich in a bohemian climate, and the majority could only be characterized as being extremely unfavorable, comprising merely 20 percent of the national average. Finally, the spatial distribution of the technological investment in response to economic scale seemed straightforward. Figure 4 showed that the level of technological investment in coastal provinces was significantly higher than the national average and in western regions. Specifically, the most 'technological' region was Shanghai, followed by other regions including Zhejiang, Guangdong and Beijing. This distinct regional division manifested that the local government in developed regions has the ability and intention to invest in technology.

In summary, the descriptive analysis in this section suggested that Florida's arguments were suitable in the context of large regions, particularly for those first-tier mega-regions (e.g., Beijing, Shanghai or Guangzhou). Clearly, a high share of bohemians and high level of technological investment co-existed with a high amount of creative workers. However, this tendency was much less obvious for the rest of the regions.

Table 1. Summary statistics of the variables included in the regressions.

\begin{tabular}{cccccc}
\hline Variable & Scale & Mean & Max & Min & Std \\
\hline GDP per capita $(1990=100)$ & $\ln$ & 6.69 & 9.19 & 4.56 & 0.70 \\
Technology index (TE) & $\%$ & 1.13 & 9.93 & 0.010 & 1.63 \\
Locational quotient of bohemians (TO) & LQ & 0.90 & 7.81 & 0.017 & 0.42 \\
Creative population (CR) & $\%$ & 3.96 & 39.98 & 0.20 & 2.31 \\
Average wage (W) & $\ln$ & 10.03 & 16.81 & 1.31 & 0.92 \\
The number of universities (per 10,000 population) (UNI) & $\ln$ & -3.39 & 4.54 & -3.36 & 0.80 \\
The number of theaters (per 10,000 population) (THE) & $\ln$ & -3.17 & -0.05 & -5.57 & -0.05 \\
Per capita green area (hectare) (GEN) & $\mathrm{ln}$ & 2.14 & 8.90 & -3.88 & 1.08 \\
\hline
\end{tabular}

Note: $\ln =$ natural log transformed, LQ = locational quotient. Source: China City Statistical Yearbook (2002-2014).

Table 2. Correlation tests of variables included in the analyses.

\begin{tabular}{|c|c|c|c|c|c|c|c|c|}
\hline & GDP per Capita & TE & TO & CR & $\mathbf{W}$ & UNI & THE & GEN \\
\hline GDP per capita & 1 & & & & & & & \\
\hline $\mathrm{TE}$ & $\begin{array}{c}0.416^{* * *} \\
(0.000)\end{array}$ & 1 & & & & & & \\
\hline $\mathrm{TO}$ & $\begin{array}{c}0.270 * * * \\
(0.000)\end{array}$ & $\begin{array}{c}0.079 * * * \\
(0.000)\end{array}$ & 1 & & & & & \\
\hline $\mathrm{CR}$ & $\begin{array}{c}0.522 * * * \\
(0.000)\end{array}$ & $\begin{array}{c}0.243^{* * * *} \\
(0.000)\end{array}$ & $\begin{array}{c}0.753 * * * \\
(0.000)\end{array}$ & 1 & & & & \\
\hline W & $\begin{array}{c}0.583 * * * \\
(0.000)\end{array}$ & $\begin{array}{c}0.259 * * * \\
(0.000)\end{array}$ & $\begin{array}{c}0.077^{* * *} \\
(0.000)\end{array}$ & $\begin{array}{c}0.364^{* * *} \\
(0.000)\end{array}$ & 1 & & & \\
\hline UNI & $\begin{array}{c}0.381^{* * *} \\
(0.000)\end{array}$ & $\begin{array}{c}0.169 * * * \\
(0.000)\end{array}$ & $\begin{array}{c}0.415^{* * *} \\
(0.000)\end{array}$ & $\begin{array}{c}0.427 \text { *** } \\
(0.000)\end{array}$ & $\begin{array}{c}0.153^{* * *} \\
(0.000)\end{array}$ & 1 & & \\
\hline THE & $\begin{array}{c}0.154^{* * *} \\
(0.000)\end{array}$ & $\begin{array}{l}0.030^{*} \\
(0.079)\end{array}$ & $\begin{array}{c}0.112 * * * \\
(0.000)\end{array}$ & $\begin{array}{c}0.118^{* * *} \\
(0.000)\end{array}$ & $\begin{array}{l}-0.008 \\
(0.659)\end{array}$ & $\begin{array}{c}0.044^{* * *} \\
(0.009)\end{array}$ & 1 & \\
\hline GEN & $\begin{array}{c}-0.0301 \text { * } \\
(-0.065)\end{array}$ & $\begin{array}{c}-0.124^{* * *} \\
(0.000)\end{array}$ & $\begin{array}{c}0.114^{* * *} \\
(0.000)\end{array}$ & $\begin{array}{c}-0.103^{* * *} \\
(0.000)\end{array}$ & $\begin{array}{c}-0.331^{* * *} \\
(0.000)\end{array}$ & $\begin{array}{c}0.191^{* * *} \\
(0.000)\end{array}$ & $\begin{array}{c}0.189 * * * \\
(0.000)\end{array}$ & 1 \\
\hline
\end{tabular}

Note: Sig: ${ }^{*} p<0.1,{ }^{* * *} p<0.01$. 


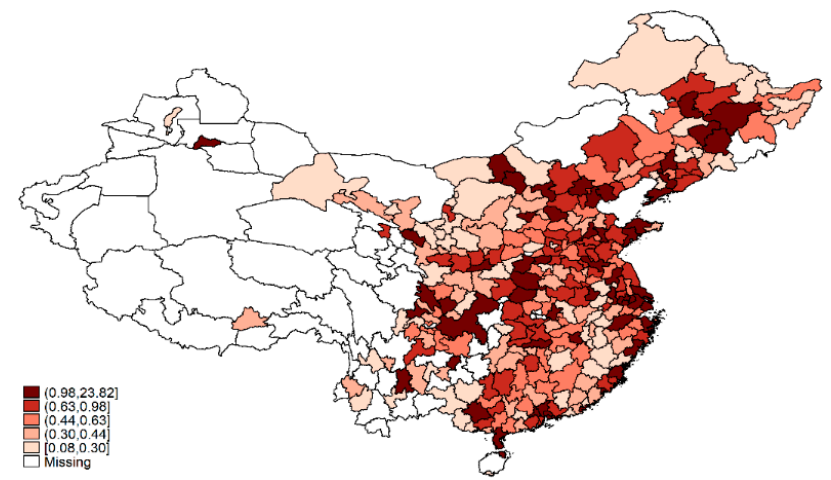

Figure 2. The distribution of the creative class at the regional level in the Mainland China.

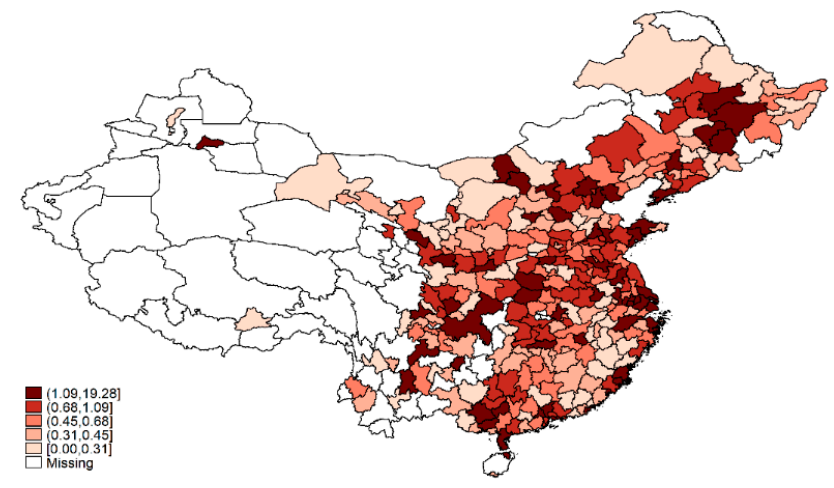

Figure 3. The distribution of the bohemian population (tolerance) at the regional level in the Mainland China.

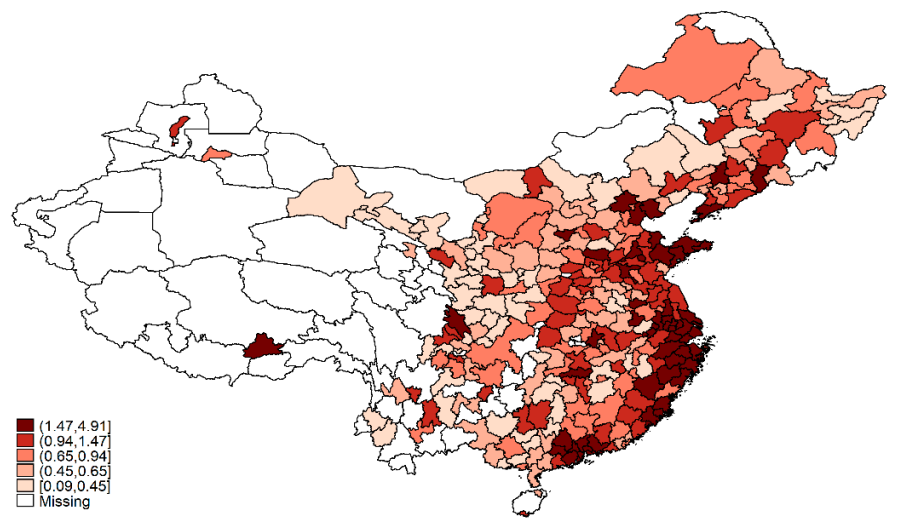

Figure 4. The development level of technology and science at the regional level in the Mainland China.

\subsection{Econometric Analysis}

In this section, econometric models are included in Table 3, which directly estimate the impacts of creative labour in association with another innovation driven factors such as technology, milieu, social provision, etc. to economic performance. First, only the key independent variables, namely the creative class, tolerance and technology, were included in the baseline model regressions (Model I) to avoid bias caused by multicollinearity or mediating effects of additional control variables. As can be seen in Model 1, the time and city dummies were also included in Models 2 and 3. The results showed that the coefficient of the density of the creative class was 0.121 and that of the development level of technology was 0.118 , both reaching the level of significance $(p<0.01)$. By contrast, the influence of the overall tolerant climate on regional economic performance was not significant until the between-group and with-in group variations were controlled. As shown in Model 2, the coefficient of tolerance was 
-0.223 , whereas it was 0.048 in Model 3. This opposite result indicated that a higher tolerant climate was associated with more GDP per capital at the city level. However, such a 'magnet effect' could not be observed at the aggregate level. Next, the control variables, including average wage, number of universities and theaters and per capita green space were added to Model 4. The findings indicated positive relationships between regional growth and these 'soft' environmental elements, while the strong and evident effects of the creative class, technology and tolerance remained unchanged.

This study further investigated the interactive effect between different ' $\mathrm{T}$ 's on regional economic growth. The interaction between the creative class and technology was significantly positive in Model 5 , whereas the coefficients of the main variables were both insignificant. This result indicated that the total effect of each interacted variables only depends on the level change of creative labour or technological investment. In this case, a higher level of creative labour flows exerted a significantly higher effect on the GDP per capita growth with a higher level of technological investment than with a lower investment level. Similarly, the positive effect of investment in technology was magnified with a higher population density of the creative class. Moreover, the interaction between tolerance and technology was also significantly positive (Model 6), while only the coefficient of the tolerance reached the level of significance. This finding implied that the total effect of tolerant milieu on economic growth depends on not only the present 'stock' of tolerance in a city but also the level change of technological investment. In comparison, the total effect of technology is only determined by the level change of tolerance. Finally, despite the significantly positive effects of the density of the creative class and the level of tolerance, their interaction was significantly negative in Model 7. This signified that the positive effect of a higher level of the creative class density on economic growth was weakened with a higher level of tolerance in a city, while a city with a higher level of tolerance also did not receive economic benefits from being featured as 'creative class-intensive'.

\subsection{Robustness Test}

\subsubsection{The Creative Class versus Non-Creative Workers}

In Table 4, we further develop the different econometric models to test the sensitivity of our results with respect to research variable definition and simultaneity. First, the measure of the creative class in this study is based on the sectoral data, which may not reflect a unique position of the creative occupations in relation to production. Given this, the category of non-creative workers, namely the share of employees who work in the sectors that are not included in Equation (1), was also incorporated within the analytical model. These categories were used to analyse, not only the creative class, but also the associated effects from non-creative workers. If the indicator of the creative class exhibited a stronger power in explaining economic growth, then the magnitude of the coefficient is likely to be larger than that of non-creative workers too. As Model 8 shows, even though with a higher share, the coefficient of non-creative workers was 0.005 , whereas the creative class was 0.009 ; all reached the level of significance. This finding implies that changes in regional creative labour demonstrated stronger explanatory power when explaining GDP per capita growth, in comparison to changes in non-creative labour. Similarly, further incorporating the interactive term between non-creative works and tolerance or non-creative workers and technology in Model 9 and 10 did not change the previous conclusions: The co-existence of the creative class and technology can result in a greater change to output through a positive interactive effect. The density of the creative class is still negatively associated with the level of tolerance. However, the interactive effect between non-creative workers and technology was significantly negative, and an interactive effect between non-creative workers and tolerance was even unobserved.

\subsubsection{Dynamic Effects Control}

Next, we turn to the model specification shown in Equation (2). As the normal demeaning process, based on the fixed effects model further creates a correlation between lagged dependent 
variable and the error term on the right side of the regression, endogeneity still cannot be removed. In this case, a dynamic GMM estimator is employed to deal with this issue and all coefficients are interpreted as long-run effects. Model 11 shows that the long-run coefficients of the creative and tolerance were $(0.041-0.061) /(1-0.883)=-0.171$ and $(0.056-0.164) /(1-0.883)=-0.958$, whereas that of the interactive term was $(-0.005+0.020) /(1-0.883)=0.128$; all reached the level of significance. The current coefficient of the interactive term is -0.005 . Because its 1 period lagged coefficient was 0.020, the total effect became a positive value. This finding shows a different pattern compared to Model 7, but the relationship between the creative class and tolerance is still consistent with the fixed effects model predicted. A positive effect of the creative class on economic growth can be only observed at the cities where the value of tolerance is above $(0.171 / 0.128=1.335)$. Similarly, if a positive effect of tolerance on economic growth is maintained, the density level of the creative class has to be greater than $(0.958 / 0.128=7.484)$. However, the cities that achieved this standard only account for $403 / 3619^{*} 100=11.1 \%$, and $226 / 3619^{*} 100=6.2 \%$, respectively over the total sample. By the same token, the short-run coefficients of the creative class, tolerance and the interactive term were $0.031,0.077$ and -0.006 respectively in Model 7. If the positive effect of the creative class and tolerance on economic growth can be maintained, the 'stock' of tolerance and the creative class must be greater than 5.167 and 7.667. Once again, qualified cities with a such a high level of tolerance is hardly observed and there is only $\left(209 / 3619^{*} 100=5.7 \%\right)$ of cities that have enough creative labour. Therefore, it is believed that the conclusion obtained from the dynamic GMM estimator is similar to previous findings based on the fixed effects model, that is, the co-existence of people climate and the creative class failed to well explain the uneven level of economic growth at the city level in China. By contrast, the results in Model 12 and 13 were not significantly different compared to the fixed effects estimators predicted in Model 5 and 6 . For instance, the long run coefficient of the interaction between the creative class and technology was $(0.002+0.003) /(1-0.838)=0.031$, while the long run coefficient of the creative class became significant compared to Model 5 , with a coefficient of $(0.022 /(1-0.838)=0.135)$, and the long run coefficient of the interaction between technology and tolerance was $(0.008 /(1-0.857))=0.056$. Overall, it is believed that the results are robust across different model specifications.

Table 3. Empirical results for testing the direct and interactive effects of the variables included.

\begin{tabular}{|c|c|c|c|c|c|c|c|}
\hline GDP & Model 1 & Model 2 & Model 3 & Model 4 & Model 5 & Model 6 & Model 7 \\
\hline CR & $\begin{array}{c}0.121 * * * \\
(0.007)\end{array}$ & $\begin{array}{c}0.178^{* * *} \\
(0.011)\end{array}$ & $\begin{array}{c}0.015^{* * *} \\
(0.004)\end{array}$ & $\begin{array}{c}0.012 * * * \\
(0.005)\end{array}$ & $\begin{array}{c}0.003 \\
(0.005)\end{array}$ & $\begin{array}{l}0.009 * \\
(0.005)\end{array}$ & $\begin{array}{c}0.031^{* * *} \\
(0.002)\end{array}$ \\
\hline $\mathrm{TO}$ & $\begin{array}{l}-0.014 \\
(0.035)\end{array}$ & $\begin{array}{c}-0.223 \text { *** } \\
(0.047)\end{array}$ & $\begin{array}{c}0.048^{* * *} \\
(0.017)\end{array}$ & $\begin{array}{c}0.050 * * * \\
(0.022)\end{array}$ & $\begin{array}{c}0.075^{* * *} \\
(0.023)\end{array}$ & $\begin{array}{c}0.043^{* * *} \\
(0.022)\end{array}$ & $\begin{array}{c}0.077^{* * *} \\
(0.022)\end{array}$ \\
\hline $\mathrm{TE}$ & $\begin{array}{c}0.118 \text { *** } \\
(0.006)\end{array}$ & $\begin{array}{c}0.110^{* * *} \\
(0.006)\end{array}$ & $\begin{array}{c}0.005^{* * *} \\
(0.003)\end{array}$ & $\begin{array}{l}0.007 \text { ** } \\
(0.003)\end{array}$ & $\begin{array}{l}-0.005 \\
(0.004)\end{array}$ & $\begin{array}{l}-0.004 \\
(0.006)\end{array}$ & $\begin{array}{l}0.007^{* *} \\
(0.003)\end{array}$ \\
\hline W & & & & $\begin{array}{c}0.037 * * * \\
(0.013)\end{array}$ & $\begin{array}{c}0.040 * * * \\
(0.011)\end{array}$ & $\begin{array}{c}0.038^{* * *} \\
(0.013)\end{array}$ & $\begin{array}{c}0.035 * * * \\
(0.013)\end{array}$ \\
\hline UNI & & & & $\begin{array}{c}0.150 * * * \\
(0.011)\end{array}$ & $\begin{array}{c}0.151 \text { *** } \\
(0.011)\end{array}$ & $\begin{array}{c}0.150^{* * *} \\
(0.011)\end{array}$ & $\begin{array}{c}0.145 * * * \\
(0.011)\end{array}$ \\
\hline THE & & & & $\begin{array}{c}0.019 * * * \\
(0.006)\end{array}$ & $\begin{array}{c}0.019 \text { *** } \\
(0.006)\end{array}$ & $\begin{array}{c}0.019^{* * *} \\
(0.006)\end{array}$ & $\begin{array}{c}0.018^{* * *} \\
(0.006)\end{array}$ \\
\hline GEN & & & & $\begin{array}{c}0.024^{* * *} \\
(0.007)\end{array}$ & $\begin{array}{c}0.025 \text { *** } \\
(0.007)\end{array}$ & $\begin{array}{c}0.024^{* * *} \\
(0.007)\end{array}$ & $\begin{array}{c}0.022 \text { *** } \\
(0.007)\end{array}$ \\
\hline $\mathrm{CR} \times \mathrm{TO}$ & & & & & & & $\begin{array}{c}-0.006^{* * *} \\
(0.001)\end{array}$ \\
\hline $\mathrm{TO} \times \mathrm{TE}$ & & & & & & $\begin{array}{l}0.013^{* *} \\
(0.006)\end{array}$ & \\
\hline $\mathrm{CR} \times \mathrm{TE}$ & & & & & $\begin{array}{c}0.003 \text { *** } \\
(0.001)\end{array}$ & & \\
\hline Constant & $\begin{array}{c}6.094 * * * \\
(0.024)\end{array}$ & $\begin{array}{c}5.769 * * * \\
(0.042)\end{array}$ & $\begin{array}{c}6.106^{* * *} \\
(0.055)\end{array}$ & $\begin{array}{c}6.405^{* * *} \\
(0.144)\end{array}$ & $\begin{array}{c}6.398 * * * \\
(0.143)\end{array}$ & $\begin{array}{c}6.407^{* * *} \\
(0.144)\end{array}$ & $\begin{array}{c}6.340 * * * \\
(0.144)\end{array}$ \\
\hline Year dummies & No & Yes & Yes & Yes & Yes & Yes & Yes \\
\hline City dummies & No & No & Yes & Yes & Yes & Yes & Yes \\
\hline Observation & 3618 & 3618 & 3618 & 3116 & 3116 & 3116 & 3116 \\
\hline $\mathrm{R}^{2}$ & 0.28 & 0.32 & 0.93 & 0.93 & 0.93 & 0.93 & 0.93 \\
\hline
\end{tabular}

Notes: Robust standard errors in parentheses; Sig: ${ }^{*} p<0.1,{ }^{* *} p<0.05,{ }^{* * *} p<0.01$, dependent variable: GDP per capita. 
Table 4. Empirical results for testing variable definition and dynamic GMM model.

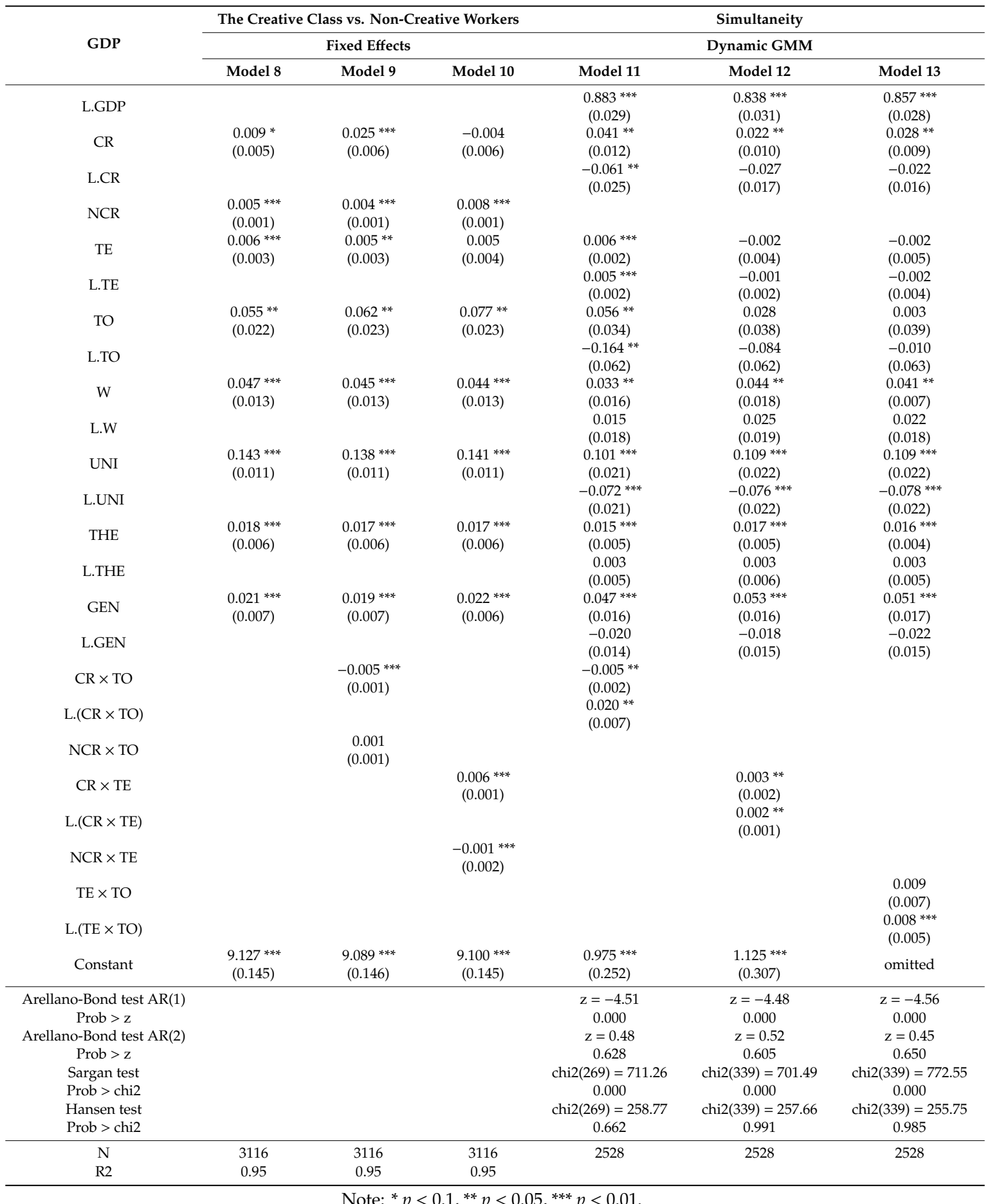

Note: ${ }^{*} p<0.1,{ }^{* *} p<0.05,{ }^{* * *} p<0.01$. 


\section{Discussion and Conclusions}

\subsection{Subsection Discussion}

\subsubsection{General Findings}

This paper has examined the creative class theory in the Chinese context. Rather than being a simple replication of the previous analyses, this study has introduced several new indicators that differ from those employed by Florida in an attempt to capture the key perspectives of the creative class thesis. Consequently, the main research question of this study has been related, not so much to how the presence of the creative class facilitates GDP per capita growth, but as to how the concept of creativity can be employed in a broader context. The answer to the research question is that many of the relationships proposed by Florida [2,30] have also been evident in China. The presence of '3Ts' has exerted significantly positive effect on economic growth at the city level in China. The complementary effects have been evident between technology and the creative class, and technology and tolerance. These results have been robust when further taking into consideration dynamic effects. Therefore, positive relationships can be found between economic growth and technological improvement, the location of the creative class, and tolerant climate respectively on average. Hypothesis 1 can be confirmed.

The present study might also capture the effect of skill-biased technological change (SBTC) during the period of economic transition in China. Along with the constant technological progress, many traditional, routine occupations will be replaced by new technologies. However, as long as artificial intelligence cannot do nearly what our minds can, it can be only complementary to creativity involved in non-routine tasks [58]. Similarly, if the creative class, as Florida suggested, mainly consists of skilled workers who can use creativity to produce socio-economic values, it should have a complementary rather than substitutive relationship with technology. As a result, our finding supports this assumption. Moreover, the positive relationship between technology and tolerance can be deemed realistic, as a tolerant working environment facilitates cooperative innovation within organizations and among individuals, thus improving the social-economic benefit of technology investment eventually [59]. Over the last decade, many city or provincial authorities in China have adopted antidiscrimination policies that prohibit discrimination on the grounds of gender identity, household registration, non-communicable diseases or even sexual orientation. Despite the fact that no such national policy has been on the legislative drawing board, the actual effects of these early attempts on economic activities were observed in this study. However, we still cannot accept Hypothesis 2, as the strengthened effect of the creative class on economic growth through building up a 'tolerant' milieu is not evident.

\subsubsection{The Creative Class, Tolerance, and Open Innovation}

In this section, particular attention has been given to the links between the presence of the creative class, the concept of tolerance and open innovation system. As Rasiah [50] emphasized, a mature innovation network should be (1) efficiently open to stimulate knowledge flows, transfer and creation; (2) can facilitate innovation agents to coordinate and exchange knowledge, ideas and experiences. Therefore, if the regional open innovation system in China is generally efficient, a co-location of tolerant climate, creative workers and positive socio-economic outcome should be evident. However, this network cohesion is not observed at the city level. The finding reveals that unlike many studies that asserted the positive effects of such a milieu, interacting the creative class and the level of tolerance interferes with economic growth. This suggests that, when analyzing the interactions between innovation driven factors, the current creative class thesis is not a completely relevant theoretical framework for the purpose of understanding the preferences and actual needs of highly skilled workers and the overall economic growth in China. It is possible that the creative class has different channels for realizing economic and social values, which have not been mentioned by the creative class theory. 
According to Asheim and Hansen [39], one plausible explanation is that the sub-groups of the creative class may share different preferences and values. Analytical occupations are related to a scientific climate, yet business climate and artistic climate are likely to be preferred by synthetic and symbolic occupations respectively. Therefore, it is possible that the tolerant climate is not the first choice for all creative workers to realize their social and economic values on average. Another reason might be that the household registration system constraints the flow of population, and weakens the role of the creative class within the knowledge intensive economy. In China, the spatial distribution of knowledge and technology intensive industries to a great extant is still determined by production, assembly and processing costs rather than by the quality of cultural environment. Thus, contrary to the assumption of 'jobs follow people', a large number of firms are located in regions with low density of creative population. Consistent with the findings of previous studies, the result suggested a negative or insignificant relationship between the location of the creative class and the corresponding contribution ratio of high-tech industries to the total GDP growth in China (e.g., [55]). In other words, the complex interplay between social life and urban amenities has not yet been connected with economic growth. Finally, from the perspective of building up an open innovation system, this result may also imply that the network cohesion between different economic agents is weak and the associated institutions have yet played crucial roles to strengthen these links. In the context of the co-location between tolerance and the creative class, this particularly means that the present innovation system is not open enough to attract creative talents, firms and other organizations, and to help them more effectively interact with each other. Here, the concept of tolerance takes on new meaning too, which represents an essential aspect of functional needs of an innovation system, in addition to the cultural consumption of a group of specific workforce only.

\subsection{Theoretical Implications}

Based on the above findings, this paper, to a great extent, explored the future development path of the creative class theory. Instead of extensively focusing on a 'one-size-fits-all' solution, the present study suggests a 'three-phrase theory', which has quite a generic and flexible focus from different perspectives. We expect that different policy packages will be effective in different stages of creative economy development, including: (1) On the formation stage, increasing the level of regional attractiveness is the primary policy focus. The perspective should be shifted to several essential aspects of economic and social progress regarding the identities of the creative class such as spatial and institutional conditions; (2) on the collaborative stage, the number of factors including the creative class within the regional innovation system can be brought together through several dimensions of proximity. The more proximity (e.g., location, talents, technology, institution, etc.) is established, the more efficiently factors would communicate and exchange innovative ideas and stay ahead of Schumpeterian creative destruction. When research is applying and testing this concept, the policy question is 'to what extent a shortage on one dimension of proximity can be compensated by a higher level proximity on another dimension' [50]; (3) on the optimization stage, providing incentives for improving networking within a regional innovation system is very important. This requires smart and flexible innovation governance at the city level, such as financing and encouraging collaborated innovation projects or providing physical convenience for information exchange and sharing.

\subsection{Policy Implications}

Florida's advocacy of generating creative competitiveness across cities and regions, by building up selected amenities may be arguable, but the creative class is substantially contributing to regional economic growth. However, it has to be admitted that the creative class may have a unique mix of formation mechanism, coordination and optimization mechanism with other innovative elements in different contexts. Therefore, compared to the creative class theory's original emphasis on 'cultural consumption', the creative class theory with Chinese characteristics signals that the existing theoretical research on talent development should not only pay attention to socio-economic preferences of 
individuals, but also pay attention to the collectivistic effect of the 'class' on the social order and innovative resources. For example, while the government management system, science and technology, culture and the market as the auxiliary elements of the creative class, and its social and economic characteristics as the core element, a development theory framework can be established to break through the barriers between innovation subjects, and fully release the vigour of innovation elements, such as talent, capital, information and technology.

Our findings have a range of policy and managerial implications. First, the present research and relevant policies are not clear enough in defining the innovative talent group, and using the 'professional' background as the standard cannot appropriately explain the current formation mechanism of innovative talents. Therefore, discussing the connotation and definition of innovative talents is significant for the research on innovation-driven economic growth, and the retention and encouragement of innovative talents in organizations. The definition on the connotation of innovative talent group by creative class theory will provide a practical basis for policy intervention in talent structure improvement of regions and cities in China, and supplementing highly-skilled and inter-disciplinary talents. Second, the development mode of innovative talents in China lacks a delicate depiction at present, and a large number of policymakers from regions and cities are keen to a 'bidding war'. This sort of policy intervention to a certain extent, wastes a lot of public resources, and caused the vicious competition between cities by constantly offering favorable terms. Taking the creative class as the representative index for measuring the innovative group, and exploring its relationship with other main innovation-driven factors, helps to further clarify that the key to the talent development mechanism is not 'favorable terms', but an excellent policy, social, industrial and institutional environment. Third, the creative class theory helps to refine the mechanism between collaborative innovation and sustainable urban economic development. Having been enlightened by the seminal work on the innovative network optimization, which takes the creative class as a core driver, and other major innovation-driven elements as auxiliary drivers, the priority of urban innovation development in China must be identifying key constraints, and optimizing the existing implementation framework of collaborative innovation.

The main limitation of the research was that the creative class is measured by the data available at the sector level. Also, other factors which can contribute to economic growth were not taken into consideration in a temporal order, such as basic infrastructures, R\&D investment, FDI, etc. However, the harmonised data was not readily available at the city level. These limitations indicate two viable research directions: (1) Directly focusing on the creative occupations to conduct a deeper analysis regarding the role of the creative class within the regional innovation system in China; (2) compiling a detailed database for regional analysis in China.

Author Contributions: K.Z. designed the study; J.Z. and X.L. analyzed the data; K.Z. and Y.Z. wrote the paper; J.Z. restructured, polished and revised the paper. All authors have read and agreed to the published version of the manuscript.

Funding: Authors thank the financial aids from Chinese Postdoctoral Science Foundation (Grant No. 2017M613092) and Social Science Foundation of Shaanxi (Grant No. 2019D035).

Acknowledgments: Helpful comments were received from anonymous reviewers.

Conflicts of Interest: The authors declare no conflict of interest. 


\section{Appendix A}

Table A1. Matching ISOC-88 codes with the industry classification standard in China.

\begin{tabular}{|c|c|c|}
\hline $\begin{array}{l}\text { The Industry Classification Standard in } \\
\text { China }\end{array}$ & $\begin{array}{l}\text { ISCO-88 } \\
\text { Code }\end{array}$ & The Definition of the Creative Class \\
\hline \multirow{5}{*}{$\begin{array}{l}\text { Type I: the number of employees } \\
\text { employed in health, sports and welfare } \\
\text { sectors }\end{array}$} & 322 & $\begin{array}{l}\text { Modern health associate professionals (except } \\
\text { nursing) }\end{array}$ \\
\hline & 323 & Nursing and midwifery associate professionals \\
\hline & 223 & Nursing and midwifery professionals \\
\hline & 324 & Traditional medicine practitioners and faith healers \\
\hline & 346 & Social work associate professionals \\
\hline \multirow{2}{*}{$\begin{array}{l}\text { Type II: the number of employees } \\
\text { employed in finance and insurance sectors }\end{array}$} & 341 & Finance and sales associate professionals \\
\hline & 342 & Business services agents and trade brokers \\
\hline \multirow{10}{*}{$\begin{array}{l}\text { Type III: the number of employees } \\
\text { employed in cultural, education, } \\
\text { broadcasting and movie sectors }\end{array}$} & 231 & $\begin{array}{l}\text { College, university and higher education teaching } \\
\text { professionals }\end{array}$ \\
\hline & 233 & $\begin{array}{l}\text { Primary and pre-primary education teaching } \\
\text { professionals }\end{array}$ \\
\hline & 232 & Secondary education teaching professionals \\
\hline & 234 & Special education teaching professionals \\
\hline & 235 & Other teaching professionals \\
\hline & 245 & Writers and creative or performing artists \\
\hline & 347 & $\begin{array}{l}\text { Artistic, entertainment and sports associate } \\
\text { professionals }\end{array}$ \\
\hline & 521 & Fashion and other models \\
\hline & 3131 & $\begin{array}{l}\text { Photographers and image and sound recording } \\
\text { equipment operators }\end{array}$ \\
\hline & 114 & Senior officials of special-interest organisations \\
\hline \multirow{11}{*}{$\begin{array}{l}\text { Type IV: the number of employees } \\
\text { employed in scientific research and } \\
\text { integrated technological services sectors }\end{array}$} & 211 & Physicists, chemists and related professionals \\
\hline & 212 & $\begin{array}{l}\text { Mathematicians, statisticians and related } \\
\text { professionals }\end{array}$ \\
\hline & 213 & Computing professionals \\
\hline & 214 & Architects, engineers and related professionals \\
\hline & 221 & Life science professionals \\
\hline & 222 & Health professionals (except nursing) \\
\hline & 243 & $\begin{array}{l}\text { Archivists, librarians and related information } \\
\text { professionals }\end{array}$ \\
\hline & 244 & Social science and related professionals \\
\hline & 247 & Public service administrative professionals \\
\hline & 321 & $\begin{array}{l}\text { Life science technicians and related associate } \\
\text { professionals }\end{array}$ \\
\hline & 311 & Physical and engineering science technicians \\
\hline \multirow{8}{*}{$\begin{array}{l}\text { Type V: the number of employees } \\
\text { employed in different sectors }\end{array}$} & 121 & Directors and chief executives \\
\hline & 122 & Production and operations department managers \\
\hline & 123 & Other department managers \\
\hline & 131 & General Managers \\
\hline & 241 & Business professionals \\
\hline & 242 & Legal professionals \\
\hline & 312 & Computer associate professionals \\
\hline & 112 & Senior government officials \\
\hline \multirow{6}{*}{ Type VI: others } & 113 & Traditional chiefs and heads of villages \\
\hline & 313 & Optical and electronic equipment operators \\
\hline & 314 & Ship and aircraft controller and technicians \\
\hline & 315 & Safety and quality inspectors \\
\hline & 343 & Administrative associate professionals \\
\hline & 345 & Police inspectors and detectives \\
\hline
\end{tabular}




\section{References}

1. Rodrigues, M.; Franco, M. Composite index to measure cities' creative performance: An empirical study in the Portuguese context. Sustainability 2019, 11, 774. [CrossRef]

2. Florida, R. The Rise of the Creative Class; Basic Books: New York, NY, USA, 2002.

3. Waitt, G.; Gibson, C. Creative small cities: Rethinking the creative economy in place. Reg. Stud. 2009, 46, 1223-1246. [CrossRef]

4. Ponzini, D.; Rossi, U. Becoming a creative city: The entrepreneurial mayor, network politics and the promise of an urban renaissance. Urban Stud. 2010, 47, 1037-1057. [CrossRef]

5. Batabyal, A.; Nijkamp, P. Human capital use, innovation, patent protection, and economic growth in multiple regions. Econ. Innov. New Technol. 2013, 22, 113-126. [CrossRef]

6. Scott, A.J. Beyond the creative city: Cognitive-cultural capitalism and the new urbanism. Reg. Stud. 2014, 48, 565-578. [CrossRef]

7. Marrocu, E.; Paci, R. Education or creativity: What matters most for economic performance? Econ. Geogr. 2012, 88, 369-401. [CrossRef]

8. Peck, J. The struggling with creative class. Int. J. Urban. Reg. 2005, 29, 740-770. [CrossRef]

9. Hansen, H.K.; Niedomysl, T. Migration of the creative class: Evidence from Sweden. J. Econ. Geogr. 2009, 9, 191-206. [CrossRef]

10. Reese, L.; Faist, J.L.; Sands, G. Measuring the creative class: Do we know it when we see it? J. Urban Aff. 2010, 32, 345-366. [CrossRef]

11. Scott, A.J. Creative cities: Conceptual issues and policy questions. J. Urban Aff. 2006, 28, 1-17. [CrossRef]

12. Scott, A.J. Jobs or amenities? Destination choices of migrant engineers in the USA. Reg. Sci. 2010, 89, 43-63. [CrossRef]

13. Glaeser, E.L. Review of Richard Florida's the rise of the creative class. Reg. Sci. Urban Econ. 2005, 35, 593-596. [CrossRef]

14. Boschma, R.A.; Fritsch, M. Creative class and regional growth: Empirical evidence from seven European countries. Econ. Geogr. 2009, 85, 391-423. [CrossRef]

15. Storper, M.; Scott, A.J. Rethinking human capital, creativity and urban growth. J. Econ. Geogr. 2009, 9, 147-167. [CrossRef]

16. Neal, Z. Creative employment and jet set Cities: Disentangling causal effects. Urban Stud. 2012, 49, $2693-2709$. [CrossRef]

17. Stolarick, K.; Currid-Halket, E. Creativity and the crisis: The impact of creative workers on regional unemployment. Cities 2013, 33, 5-14. [CrossRef]

18. Luger, D. When the creative class strikes back: State-led creativity and its discontents. Geoforum 2019, 106, 330-339. [CrossRef]

19. Trillo, C. The rise of the co-creative class: Sustainable innovation-led urban regeneration. In International Symposium on New Metropolitan Perspectives; Springer: Cham, Switzerland, 2018; Volume 100, pp. 411-421.

20. Zhao, K.; O'Mahony, M.; Qamar, A. Bridging the gap in creative economy and ICT research: A regional analysis in Europe. Appl. Econ. 2020. [CrossRef]

21. Jiang, Y.F.; Qian, Q.L.; Zhang, X.L.; Chen, Y.B. The formation of government-oriented creative community and its driving mechanisms: A case study of the $39^{\circ}$ space art creative community in Foshan, China. Sustainability 2019, 11, 625. [CrossRef]

22. Hong, J.; Yu, W.T.; Yang, F.L. The spatial distribution of human capital and the creative class in China. Economists 2011, 9, 28-35.

23. Wang, M.; Xuan, Y.; Chen, Q.W. The agglomeration of the creative class, knowledge externality and urban innovation-the evidence form 20 major cities in China. Econ. Theory Econ. Manag. 2016, 36, 59-70.

24. Barro, R.J. Government spending in a simple model of endogenous growth. J. Polit. Econ. 1990, 98, $103-125$. [CrossRef]

25. Glaeser, E.L. The Triumph of City; Penguin Books: New York, NY, USA, 2011.

26. Jones, R.; Chiripanhura, B. Measuring the UK's human capital stock. Econ. Labour Mark. Rev. 2010, 4, 36-63. [CrossRef]

27. Florida, R.; Mellander, C.; Stolarick, K. Inside The black box of regional development-Human capital, the creative class and tolerance. J. Econ. Geogr. 2008, 8, 615-649. [CrossRef] 
28. Landry, C. The Creative City: A Toolkit for Urban Innovators; Earthscan: London, UK, 2000.

29. Landry, C. Creativity and the City: Thinking though the Steps. Urban Reinventors. 2005. Available online: https://www.researchgate.net/publication/265221016_Creativity_and_the_city_Thinking_through_ the_steps (accessed on 15 May 2016).

30. Florida, R. The Rise of the Creative Class, 10th ed.; Basic Books: New York, NY, USA, 2013.

31. McGranahan, D.; Wojan, T. Recasting the creative class to examine growth processes in rural and urban counties. Reg. Stud. 2007, 41, 197-216. [CrossRef]

32. Marlets, G.; van Woerkens, C. Skills and Creativity in Across-Section of Dutch Cities. Discussion Paper Series 04-29; Koopmans Research Institute: Utrecht, The Netherlands, 2004.

33. Chapple, K.; Markusen, A.; Schrock, G. Rejoinder: High-tech rankings, specialization, and relationship to growth. Econ. Dev. Q. 2004, 18, 44-49. [CrossRef]

34. Clifton, N. The 'creative class' in the UK: An initial analysis. Geogr. Ann. Ser. B. 2008, 90, 63-82. [CrossRef]

35. Markusen, A. Urban development and the politics of a creative class: Evidence from the study of artists. Environ. Plan. 2006, 38, 1921-1940. [CrossRef]

36. Rausch, S.; Negrey, C. Does the creative engine run? A consideration of effect of creative class On economic strength and growth. J. Urban Aff. 2006, 28, 473-489. [CrossRef]

37. Wojan, T.R.; Lambert, D.M.; McGranahan, D. Emoting with their feet: Bohemian attraction to creative milieu. J. Econ. Geogr. 2007, 7, 711-736. [CrossRef]

38. Gibson, C.; Kong, L. Cultural economy: A critical review. Prog. Hum. Geog. 2005, 29, 541-561. [CrossRef]

39. Asheim, B.; Hansen, H.K. Knowledge bases, talents, and contexts: On the usefulness of the creative class approach in Sweden. Econ. Geogr. 2009, 85, 425-442. [CrossRef]

40. Krätke, S. 'creative cities' and the rise of the dealer class: A critique of Richard Florida's approach to urban theory. Int. J. Urban. Reg. 2010, 34, 835-853.

41. Nelson, R. A cultural hinterland? Searching for the creative class in the small Canadian city. In The Small Cities Book: On the Cultural Future of Small Cities; Garrett-Petts, W.F., Ed.; New Star Books: Vancouver, BC, Canada, 2004; pp. 85-110.

42. Stam, E.; Jeroen, P.; Marlet, G. Creative industries in Netherland: Structure, development, innovativeness and effects on urban growth. Geogr. Ann. Ser. B Hum. Geogr. 2008, 90, 119-132. [CrossRef]

43. Ström, P.; Nelson, R. Dynamic regional competitiveness in the creative economy: Can peripheral communities have a place? Serv. Ind. J. 2009, 30, 497-511. [CrossRef]

44. Lewis, N.M.; Donald, B. A new rubric for 'creative city' potential in Canada's smaller cities. Urban Stud. 2010, 47, 29-54. [CrossRef]

45. Kolenda, R.; Liu, C.Y. Are central cities more creative? The intrametropolitan geography of creative industries. J. Urban Aff. 2012, 34, 487-512. [CrossRef]

46. Pyka, A.; Bogner, K.; Urmetzer, S. Productivity slowdown, exhausted opportunities and the power of Human ingenuity-Schumpeter meets georgescu-roegen. J. Open Innov. Technol. Mark. Complex. 2019, 5, 39. [CrossRef]

47. Yun, Y.; Lee, M. Smart city 4.0 from the perspective of open innovation. J. Open Innov. Technol. Mark. Complex. 2019, 5, 92. [CrossRef]

48. Krishna, V. Universities in the national innovation systems: Emerging innovation landscapes in Asia-Pacific. J. Open Innov. Technol. Mark. Complex. 2019, 5, 43. [CrossRef]

49. Kodama, F. Incessant conceptual/industrial transformation of automobiles. J. Open Innov. Technol. Mark. Complex. 2019, 5, 50. [CrossRef]

50. Rasiah, R. Building networks to harness innovation synergies: Towards an open systems approach to sustainable development. J. Open Innov. Technol. Mark. Complex. 2019, 5, 70. [CrossRef]

51. Wu, D. Rethinking creative industries research: Synthesizing the creative class thesis, clustering, and global production network approaches. Geogr. Compass. 2017, 11, e12348. [CrossRef]

52. Mellander, C.; Stolarick, K.; Lobo, J. Distinguishing neighborhood and workplace network effects on individual income: Evidence from Sweden. Reg. Stud. 2017, 51, 1652-1664. [CrossRef]

53. Batabyal, A.A.; Yoo, S.J. On research and development in a model of Schumpeterian economic growth in acreative region. Technol. Forecast. Soc. 2017, 115, 69-74. [CrossRef]

54. Winden, W.; Otgaar, A.; Witte, J. Urban Innovation System: What Makes Them Tick? Routledge: New York, NY, USA, 2014. 
55. Florida, R.; Mallander, C.; Qian, H. China's development disconnect. Environ. Plan. A 2012, 3, 628-648. [CrossRef]

56. Möller, J.; Tubadji, A. The Creative Class, Bohemians an Local Labor Market Performance-A Micro-Data Panel Study for Germany 1975-2004; Arbeiten Aus Dem Osteuropa-Institut Regensburg: Regensburg, Germany, 2008.

57. Lorenzen, M.; Andersen, K. Different creative cities: Exploring Danish data to adopt the creative class argument to small welfare economies. Creat. Ind. J. 2012, 4, 123-136. [CrossRef]

58. Autor, D.H.; Katz, L.F.; Kearney, M.S. The polarization of the US labour market. Am. Econ. Rev. 2006, 96, 189-194. [CrossRef]

59. Gao, H.S.; Zhang, W. Employment nondiscrimination acts and corporate innovation. Manag. Sci. 2017, 63, 2982-2999. [CrossRef]

60. Anderson, K.V.; Hansen, H.K.; Isakson, A.; Raunio, M. Nordic regions in the creative class debate: Putting creative class thesis to a test. Ind. Innov. 2010, 2, 215-240. [CrossRef]

(C) 2020 by the authors. Licensee MDPI, Basel, Switzerland. This article is an open access article distributed under the terms and conditions of the Creative Commons Attribution (CC BY) license (http://creativecommons.org/licenses/by/4.0/). 